\title{
Evaluace pobytového programu Podblanického ekocentra
}

\author{
Jan Činčera, Petra Macháčková
}

Envigogika 2009/IV/3 - Recenzované články/ Reviewed Papers

Publikováno/Published 22. 12. 2009

DOI: http://dx.doi.org/10.14712/18023061.42

\begin{abstract}
Abstrakt:
Článek seznamuje $s$ výsledky sumativní evaluace dvouletého programu Podblanického ekocentra ČSOP Vlašim. V první fázi je charakterizován program a jeho metodika. Ve druhé jsou popsány výsledky formativní evaluace po prvním roce programu. $\checkmark$ další části je popsána metodika sumativní evaluace a jsou prezentovány hlavní výsledky. Program pozitivně ovlivnil znalosti žáků a jejich odhodlání jednat ve spotřebitelské oblasti.
\end{abstract}

\section{Klíčová slova:}

Evaluace sumativní, evaluace formativní, eko-spotřebitelství, pobytový program, Fair Trade, globální problémy, efektivita environmentální výchovy

\begin{abstract}
:
The article introduces findings of a summative evaluation of a two-year program organized by the Podbanicke eco-center CSOP Vlasim. Its methods are described in the first part the program. The second part summarizes the main findings of the formative evaluation after the first year of the program. The next part describes the goals and methodology of the summative evaluation and its findings. The program had a positive influence of pupils' knowledge and awareness, and their intention to act in an area of ecoconsumerism.
\end{abstract}

\section{Key words:}

Summative evaluation, formative evaluation, eco-consumerism, programme Fair Trade, global problems, effectiveness of environmental education 


\section{Úvod}

V České republice existují stovky až tisíce různých programů environmentální výchovy, které jsou nabízeny školám středisky ekologické výchovy a dalšími subjekty. Až na výjimky není vyhodnocováno, jaký mají tyto programy reálný dopad na znalosti, dovednosti, hodnoty, postoje a chování žákù. Podle výzkumu Činčera a kol. (2009) vyhodnocuje většina poskytovatelů programů environmentální výchovy pouze spokojenost klientely s programem, nejčastější používanou evaluační metodou je nestrukturované pozorování (Činčera, Kulich, Gollová, 2009). Evaluace je přitom základním nástrojem, který $v$ procesu kritického prověřování efektivity programů poskytuje jejich tvůrcům zásadní zpětnou vazbu $\mathrm{k}$ dalším úpravám a vývoji programu (Patton, podle Barch, Duvall, Higgs, Wolske \& Zint, 2007).

Článek se zaměřuje na formativní a sumativní evaluaci pobytového programu Podblanického ekocentra ČSOP Vlašim. Program je dosud ve vývojové fázi a informace o jeho fungování jsou proto klíčové pro jeho další vývoj. Současně jeho experimentální charakter přináší specifické komplikace pro evaluaci. Program se do značné míry vyvíjí „za pochodu", z původně roční varianty se změnil ve dvouletou a následně tríletou. Druhým rokem programu zatím prošly jen dvě tř́́dy, což $v$ podstatě znemožňuje randomizaci a snižuje statistickou sílu testovacích metod. Zpracovaná evaluace proto mủže poskytnout jen orientační výpověd' zatíženou značnými nepřesnostmi.

Vzhledem ke skutečnosti, že sumativní evaluace programů environmentální výchovy dosud $v$ České republice nejsou běžné (Činčera, Kulich \& Gollová, 2009), může článek nabídnout určitou inspiraci ostatním realizátorům environmentální výchovy a upozornit na problémy, které jsou se sumativními evaluacemi spjaty.

\section{Popis programu}

\section{Cíle a metodika prvního roku programu}

V roce 2007 otevřelo Podblanické ekocentrum ČsoP Vlašim první běh ročního programu pro žáky 6 . třídy základní školy. ${ }^{1}$ Program byl koncipován jako celoroční se dvěma tř́ídenními pobyty žáků ve středisku a provázejícími aktivitami během celého školního roku.

Hlavním tématem programu byl původ věcí. Program byl dále rozdělen do několika podtémat: dovoz, ekologická stopa, práva a ochrana zviŕat, tradiční výroba a region. Výstupy programu byly vymezeny takto (ZO ČSOP Vlašim, 2007):

Po ukončení programu žáci:

- znají prírodní a kulturní hodnoty svého regionu,

- umí vysvětlit původ a cestu potravin,

- posoudí obsah nákupního košíku z hlediska jeho dopadů na životní prostředí,

- dovedou trávit čas $v$ prírodě,

1 Protože pro motivaci žáků se $v$ programu uplatňuje motiv tajemství, které by žáci neměli odhalit př́liš brzy, neuvádíme zde záměrně přesný název programu. 
- umí upéci chleba,

- umí vyhledávat informace a pracovat s nimi,

- dovedou prezentovat výsledky své práce,

- volí variantu příznivější k životnímu prostředí,

- rádi tráví čas v přírodě,

- cítí sounáležitost se svým regionem,

- umí spolupracovat a vzájemně si naslouchat.

Program byl zpracován podle metodiky rozvíjené skupinou neformálně označovanou jako Univerzita profesora Kaktuse (Činčera, 2007). Metodika doporučuje tvořit programy jako široce koncipované integrované tematické celky (Kovalik \& Olsen, 1994). Na základě očekávaných výstupů programu je vytvořeno jedno či více širších témat. Každé téma je charakterizováno určitou hlavní myšlenkou (teze programu). Hlavní myšlenka je následně rozpracována do dílčích témat, ke kterým pak jsou připravovány konkrétní aktivity. Žák prochází plynulým tokem aktivit, které jej z různých stran konfrontují s hlavní myšlenkou tematického celku. Po poslední aktivitě je pak žákům předložena hlavní myšlenka k zamyšlení a jejímu (zpravidla) písemnému reflektování. Konfrontace žáků s tezemi programu i myšlenkami jednotlivých aktivit je chápána jako dialog, ve kterém se potkávají horizonty všech zúčastněných (Činčera, 2007). K základní stavbě programu se připojuje paralelní programová rovina tvořená aktivitami zaměřenými na formování skupiny. Obě roviny se navzájem prolínají, takže $v$ průběhu programu se střídají aktivity zařazené do struktury "teze - témata - aktivity" s aktivitami reagujícími na potřebu skupiny projít jednotlivými fázemi vývoje.

Motivace žáků procházet programem je posilována tím, že program je zarámován příběhem s tajemstvím, které žáci postupně odhalují.

Podrobný program není možné $v$ rámci článku prezentovat $\mathrm{z}$ důvodu př́lišného rozsahu (i nevhodnosti publikace $v$ online prostředí). V prvním dni pobytové části programu žáci nejprve procházeli sledem aktivit na formování skupiny a byli uvedeni do jeho legendy. Druhý den byl věnován spotřebitelství. Žáci se učili o ekoznačkách, prováděli vlastní průzkum $v$ supermarketech a formou pohybové hry se seznámili se spektrem sociálních a ekologických dopadů výrobku. Třetí den diskutovali o právech zvírat a navštívili záchrannou stanici pro zvířata.

V průběhu dalšího půl roku děti plnily navazující úkoly. Měly vyhledat odpovědi na otázky související $s$ ekologickým zemědělstvím a o vánocích připravit ekologicky orientovanou besídku. Navíc si stanovily závazek na snížení své ekologické stopy.

Druhá pobytová část se zaměřila na původ věcí. Žáci se zde učili péct chleba, navštívili venkovský statek a mapovali koloběh látek v přírodě.

Ve školním roce $2007 / 8$ se programu účastnily první dvě šesté třídy dvou regionálních základních škol.

\section{Cíle a metodika druhého roku programu}

Ve školním roce 2008/9 otevřelo středisko druhý ročník programu pro další dvě třídy. Současně se ale rozhodlo pokračovat $v$ práci $s$ oběma třídami z prvního ročníku. $\mathrm{K}$ pưvodním dvěma pobytovým akcím tak přibyla třetí a program se prodloužil z jednoho 
roku na dva². Pro tuto pokračovací část byly nastaveny nové očekávané výstupy, ve kterých středisko reagovalo na výsledky evaluační zprávy loňského ročníku. Nová část programu se měla zaměřit především na uvědomění si provázanosti mezi globálními problémy a spotřebitelským chováním žáků. Program tedy ovlivňoval vlastnické a akční proměnné $v$ modelu REB (komplexní porozumění problémům, odhodlání jednat, akční strategie, interní ohnisko kontroly) a směřoval k spotřebitelské rovině chování žáků (Hungerford \& Volk, 1990). Očekávané výstupy programy jsou uvedeny v tabulce č. 1.

Tabulka 1: Očekávané výstupy programu

\section{Očekávané výstupy programu}

\section{Postoje:}

a) Žák volí variantu příznivější pro ŽP.

\section{Dovednosti:}

a) Žák posoudí obsah svého nákupního košíku z hlediska vlivu na ŽP a lidi, kteří je vyrábějí.

b) Žák umí vyhledávat informace a pracovat s nimi (utřídí, vybere podstatné, sumarizuje atp.).

c) Žáci dovedou prezentovat výsledky své práce (poutavě, srozumitelně, strukturovaně, vhodnými metodami atp.).

\section{Kognitivní:}

d) Žáci z obalu výrobku zjistí důležité informace (země původu, ekoznačka, ...)

a) Žáci vysvětlí pojem Biopotravina, Fair Trade a FSC a poznají jejich logo.

b) Žák vysvětlí, jak se získává bavlna.

c) Žák popíše dopady pěstování bavlny na ŽP a na pěstitele $v$ zemích třetího světa.

d) Žák vysvětlí, jak souvisí dopady výroby oblečení s jeho spotřebním chováním.

e) Žák vysvětlí, jak může pozitivně ovlivnit dopady výroby textilií (alternativy).

f) Žák vysvětlí, co je palmový olej a jak s ním souvisí.

g) Žák popíše souvislost mezi pěstováním palmového oleje a kácením deštných pralesů.

h) Žák popíše, jaký dopad má kácení pralesů na místní obyvatele, na Žp Země (biodiverzita, $\mathrm{CO}_{2}, \ldots$ )

i) Žák vysvětlí pojem „dětská práce".

j) Žák vysvětlí, jak souvisí konzumace čokolády ( $v$ ČR) s dětskou prací v rozvojových zemích.

k) Žák vyjmenuje a vysvětlí alternativy ke konvenční výrobě a obchodování s čokoládou.

I) Žák pozná značku Fair Trade a vysvětlí její hlavní principy (zamezení dětské práci, spravedlivou cenu, ...)

\footnotetext{
$2 \vee$ současné době je program koncipován již jako tříletý. Žáci šesté třídy absolvují dva pobyty na středisku a průběžnou celoroční práci ve škole, $v$ sedmé tř́dě se účastní trrídenní pobytové akce a v osmé ještě jedné třídenní akce na středisku. Prezentovaná evaluace odpovídá výsledkưm žáků po druhém roce programu.
} 
V první části programu žáci nejprve prostřednictvím hry zkoumali životní cyklus výrobku (trička). Následující den byl zaměřen na problematiku deštných pralesů a mapování souvislostí mezi jejich kácením a spotřebitelským chováním ve vyspělých zemích. Žáci se seznámili se značkou Fair Trade.

Program předpokládal, že žáci pomocí simulačních her získají vztah ke zvolenému problému a prostřednictvím dalších aktivit jej budou dále zkoumat a propojovat se svým životem. To je $v$ souladu $s$ existujícími metodikami, které doporučují dělat problém konkrétním a relevantním pro žáky (Bardwell, Monroe \& Tudor, 1994). Následně žáci rozvíjeli své znalosti akčních strategií, kdy se učili souvisejícím akčním strategiím směřujícím ke spotřebitelskému chování. Podle Hungerforda a Volkové (1990) pak v důsledku získaných znalostí a dovedností akčních strategií roste odhodlání žáků $\mathrm{k}$ environmentálně odpovědné akci, které může vést $\mathrm{k}$ samotnému jednání (Hungerford \& Volk, 1990).

Vztah mezi proměnnými ovlivňovanými programem (teorii programu) Ize vyjádřit následujícím schématem:

\section{Obrázek 1: Vztahy mezi proměnnými v programu}

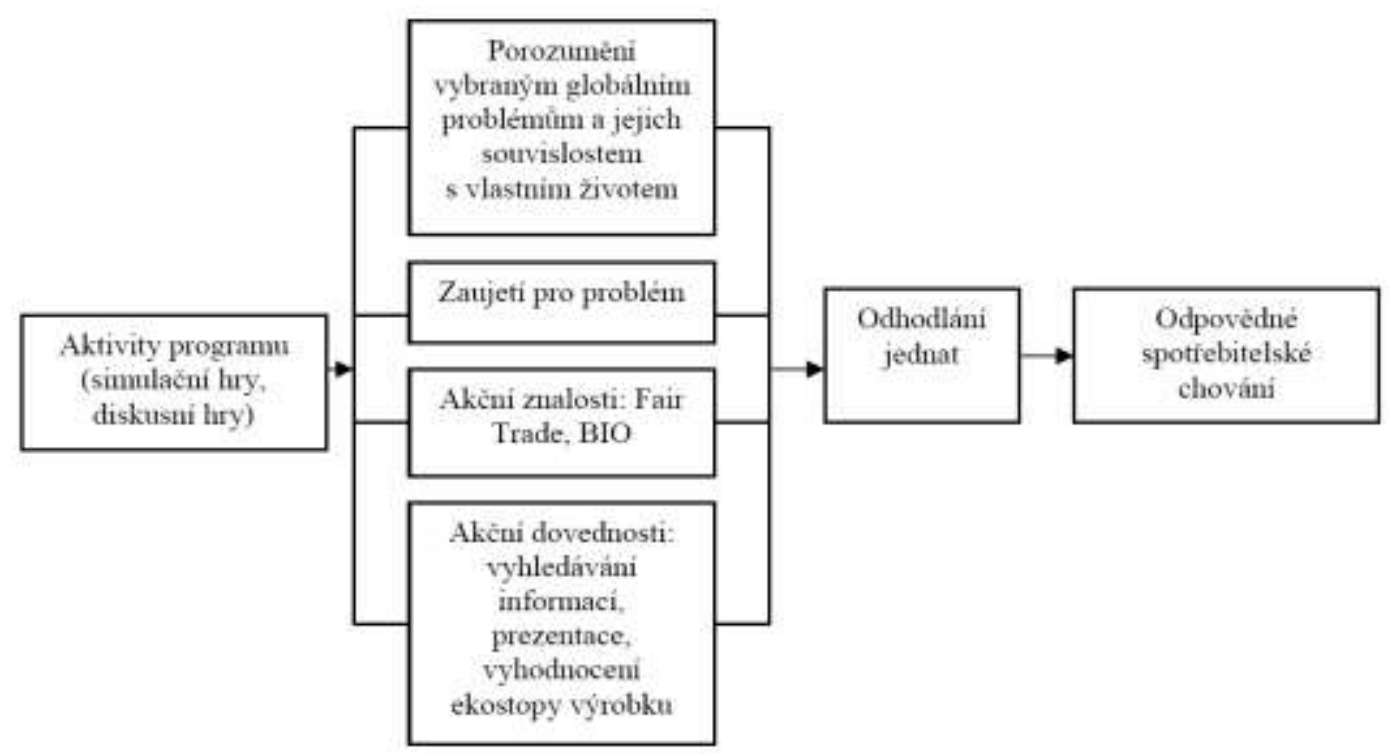

\section{Metodika evaluace}

Evaluace v oblasti environmentální výchovy slouží k posuzování hodnoty jednotlivých programů ${ }^{3}$ - na úrovni produktů, výstupů, procesů, prostředků či vztahu k využití jeho zdrojů. Rozlišuje se na evaluaci formativní, zaměřenou na analýzu implementace programu a sumativní, hodnotící míru dosažení očekávaných výstupů programu (Bennett, 1989; Barch et. al., 2008; Frechtling, 2002).

\footnotetext{
${ }^{3}$ Program se zpravidla chápe jako skupina plánovaných aktivit, které naplňují jeden či více společných cílů (Newcomer, Hatry \& Wholey, 2004).
} 
Evaluaci můžeme chápat také jako ověřování tzv. „teorie programu", tedy předpokladu tvůrců programu o kauzálních vztazích mezi vstupy, aktivitami a výstupy programu na různých úrovních (Laughlin \& Jordan, 2004; Marcinkowski, 2004). Zatímco formativní evaluace ověřuje, zda program probíhá podle plánu, sumativní evaluace ověřje, zda a do jaké míry je jeho teorie funkční.

\section{Formativní evaluace programu}

Protože program byl původně plánován jako jednoletý, byla po jeho ukončení v červnu 2008 zpracována první evaluační zpráva (Činčera, 2009). Vzhledem k jejímu rozsahu i zaměření článku na sumativní evaluaci programu jsou zde nastíněny pouze základní závěry zprávy.

Pro potřeby evaluace byl nejprve zpracován logický model programu. Na jeho základě byly stanoveny indikátory, vyjadřující kritéria úspěšnosti $v$ dosažení jednotlivých očekávaných výstupů programu. strategií:

Plán evaluace vycházel ze smíšeného evaluačního designu a kombinoval několik

- Porovnání dosažených výstupů s indikátory;

- $\quad$ Pretest-program-posttest design;

- Kvalitativní metodiku využívající pozorování, písemné reflexe žáků a jejich výstupy $v$ průběhu programu, novinové články napsané dětmi do školního časopisu, reflexi pedagogů, obrazovou reflexi žáků.

Vzorek tvořilo celkem 43 žáků šestých tříd dvou základních škol, tj. všichni žáci, kteří se zúčastnili celého programu.

Při statistickém zpracování dat byl použit párový Wilcoxonův test, $t$ test a chí kvadrát. Hladina významnosti byla ve všech případech stanovena na $a=0,05$.

Při analýze obrázků reflektujících nejsilnější okamžiky programu byly ke každému obrázku přiděleny kódy vyjadřující zachycená témata (např. návštěva katakomb), ty pak byly shromážděny pod obecnější kategorie. Následně pak byly porovnány četnosti př́padů v jednotlivých kategoriích. Ostatní reflexe byly zpracovány metodou otevřeného kódování (Hendl, 2008).

\section{Sumativní evaluace programu}

Sumativní evaluace využívala smíšený evaluační design:

- Kvazi-experiment typu experimentální skupina - kontrolní skupina.

- Porovnání dosažených výstupů spředem stanovenými indikátory (monitoring výkonu žáků);

- Analýza písemných reflexí a dalších materiálů souvisejících sprogramem.

Podkladem pro monitoring výkonu žáků i pro kvazi-experiment byl test, který žáci z experimentální i kontrolní skupiny dostali po ukončení programu. Test se skládal ze čtyř částí:

- Porozumění problémům životního prostředí. Žáci odpovídali na sérii otevřených otázek, ve kterých měli za úkol analyzovat činnost na obrázku (např. postřikování bavlny pesticidy), odvodit její dopady na životní prostředí, uvést dưvody a dưsledky kácení deštných pralesư a využívání dětské práce. 
- Znalosti akčních strategií. Žáci odpovídali na pět otázek testujících jejich znalost ekoznaček a porozumění konkrétním metodám, jak mohou sami svým chováním snižit dopady výroby textilu na životní prostředí.

- Odhodlání jednat. Žáci měli ve dvou otázkách na výběr několik značek stejného druhu výrobku (jogurtu, resp. čokolády). Z každého obrázku bylo zjevné, zda jde o výrobek, který má ekoznačku (BIO či Fair Trade) či nikoliv. Žáci měli vybrat vždy jeden výrobek, který by si koupili. U každé otázky byly vždy uvedeny dva výrobky s ekoznačkou ( $v$ tabulce označeno jako EKO) a dva bez ekoznačky (NEKO).

- Spotřebitelské chování. Ve třech otázkách byli žáci dotázáni na počet výrobků se značkou BIO, Fair Trade a FSC, které si koupili v roce 2009. Kromě zakroužkování odpovědi na číselné ose měli uvést i konkrétní príklady.

Experimentální skupina byla tvořena 22 žáky 7. třídy ZŠ, kteří se účastnili jak původního, tak pokračovacího programu střediska. Kontrolní skupinou bylo 20 žáků 8. třídy téže základní školy.

Při zpracování výsledků pro potřebu kvazi-experimentu byly statistické rozdíly ve výsledcích žáků z obou skupin na jednotlivých škálách vyhodnocovány pomocí Wilcoxonova nepárového testu, resp. chí kvadrátu. Wilcoxonův nepárový test je považován za vhodný typ testu pro ordinální typ dat, který nevznikl na základě normálního rozdělení (Hendl, 2006). Chí kvadrát byl volen pro porovnání četnosti mezi volbou výrobků s ekoznačkami vs. bez ekoznaček. Hladina významnosti byla ve všech př́padech stanovena na a=0,05.

Pro vyhodnocení monitoringu výkonu žáků byla volena metoda prostého porovnávání procentuálního podílu žáků splňujících danou podmínku s hladinou uvedenou v příslušném indikátoru. Indikátory byly definovány tvưrci programu a odráží jejich vlastní kritéria úspěšnosti programu.

Při analýze písemných reflexí byly hodnoceny závěrečné reflexe žáků vypovídající o tom, co se v programu naučili. Jednotlivé výpovědi byly kódovány a následně převáděny na obecnější kategorie. Pro orientaci byla evidována četnost výpovědí odpovídající jednotlivým kódům.

\section{Limity výzkumu}

Výsledky evaluace mohly být ovlivněny několika faktory, které souvisí s limity jednotlivých evaluačních metod, reliabilitou testu a problémy s administrací výzkumu.

Monitoring výkonu žáků (Performance monitoring), tj. metoda, při které se porovnávají skutečné výstupy programu s předem stanovenými indikátory (viz tabulka 6), sice přesně odpovídá na otázku, mají-li žáci po ukončení programu požadovanou úroveň, není $\mathrm{z}$ ní ale možné oveřit, zda $\mathrm{k}$ výsledkům došlo vlivem programu nebo $\mathrm{z}$ jiných důvodů (Poister, 2004).

Vliv programu se proto zpravidla ověřuje pomocí experimentů, které se dělí na kvazi-experimenty a randomizované experimenty.

Kvazi-experimenty jsou chápány jako určitá zjednodušená alternativa randomizovaných experimentů (Reichard \& Mark, 2004). Vzorek nevzniká náhodným výběrem ze základní množiny, ale podle jiného klíče. Ve srovnání s randomizovanými experimenty tak klesá reliabilita výsledků (Reichard \& Mark, 2004). V rámci evaluace nebylo možné provést randomizaci vzhledem $\mathrm{k}$ velikosti základní množiny. Cílem bylo proto provést census (sebrat data od všech účastníků), to se ale z organizačních důvodů nepovedlo (jedna ze dvou tř́́d neměla čas na vyplnění posttestů). Kvazi-experimentální část evaluace odpovídala na otázku, zda mezi žáky, kteří prošli programem a jejich o rok 
staršími spolužáky ze stejné školy existují statisticky významné rozdíly ve znalostech, postojích a chování, které korespondují s očekávanými výstupy programu.

Analýzy písemných reflexí a další případné metody typické pro kvalitativní metodiku typicky umožňuji hlubší vhled do programu a jeho interpretace účastníky, nelze však podle nich kvantitativně vyjádřit efekt programu. Ve spojení s kvantitativní metodikou ale poskytují důležitý zdroj dat pro interpretaci výsledků (Hendl, 2008). Z tohoto důvodu je často smíšený evaluační design upřednostňován před čistě kvantitativním či kvalitativním (Bennett, 1989).

Test použitý v kvazi-experimentu sumativní části evaluace nebyl standardizován a byl poprvé vyzkoušen na testovaném vzorku. Vzhledem $k$ malému rozsahu částí ověřujících spotřebitelské chování žáků a odhodlání jednat nebyla u nich vyhodnocována položková reliabilita. Položková reliabilita škály Porozumění problémům životního prostředí byla proto vyhodnocena až na základě výsledků žáků z obou skupin, přičemž Cronbach alfa $=0,76$, což je možné považovat za dostačující. Hodnota Cronbach alfa pro Znalosti akčních strategií byla pouze 0,5, což naznačuje, že škála měří více souvisejících proměnných. Je ale možné, že výsledek byl ovlivněn velikostí skupiny či malým počtem otázek.

Kvůli problémům s administrací se pro sumativní evaluaci nakonec podařilo získat data jen od jedné ze zapojených tříd. Žáci kontrolní skupiny prošli stejným vzdělávacím programem, jako jejich o rok mladší spolužáci, nezúčastnili se ale ani jedné části pobytového programu nabízeného střediskem. Vzhledem k tomu, že nebyl použit pretest, nelze vyloučit, že mezi oběma skupinami existovaly statisticky významné rozdíly již před zahájením programu. Malá velikost vzorku zvyšuje riziko chyby druhého typu (Newcomer \& Wirtz, 2004). Je proto možné, že evaluace neodhalila některé ze skutečných efektů programu.

\section{Prezentace výsledků evaluace}

\section{Výsledky formativní evaluace}

Výsledky první evaluace ukázaly silné i slabé stránky programu. Na reaktivní rovině měl program výborné hodnocení od žáků i učitelek. Použitá metodika umožnila děti vtáhnout do legendy, která je provázela jednotlivými aktivitami. Děti na program reagovaly značně emocionálně a spojovaly s ním řadu silných zážitků. Největším zážitkem pro děti $v$ průběhu programu byl přímý kontakt se zvířaty a rituály související s legendou programu a tajemnými místy, které v jeho průběhu navštívily.

Na rovině učení vykazoval program efekt především v dosahování znalostních cílů. Vysoký efekt program zaznamenal v ovlivnění znalosti ekologických značek a ve znalostech složení potravinářského výrobku (chleba), velikost efektu (effect size) v obou případech dosáhla hodnoty 1,8 (hodnoceno pomocí párového Wilcoxonova testu), což Ize interpretovat jako vysoký efekt programu. S tím korespondují i údaje získané ze zpětných vazeb od žáků, které naznačují určitou míru porozumění sociálním a environmentálním dopadům výrobků. Přestože průměrné výsledky žáků nedosáhly úrovně požadované př́slušnými výstupy, dostali se žáci $z$ úrovně téměř nulového povědomí $\mathrm{k}$ průměrnému porozumění problematice.

Přestože pro vyhodnocení míry, se kterou žáci porozuměli environmentálním a sociálním dopadům výrobků, nebyly $\mathrm{k}$ dispozici dostačující data, prokázal program uvědomění si nových skutečností žáky. Nové bylo zejména uvědomění si sociálních dopadů výrobku na životní podmínky $v$ rozvojových zemích, které bylo často emocionálně prožíváno. Program pravděpodobně pomohl rozvinout vybrané dovednosti žáků, související 
se zpracováváním a prezentací informací. Vzhledem k neexistenci přesných evaluačních nástrojů ale tento vliv nebylo možné specifikovat.

Porovnání pretest-posttest na druhé straně nepotvrdilo, že by program ovlivňoval znalosti prírodních a kulturních hodnot regionu. Stejná metoda dále prokázala mírný vliv na atraktivitu pobytu $v$ př́rodě pro děti ( $u$ jedné ze sledovaných trríd $t=2,58, p=0,02$, velikost efektu $=0,37)$.

Program dále neprokázal vliv na chování žáků ve vztahu k preferenci výletů do př́rody ve volném čase. Na hranici statistické významnosti byl zaznamenán možný vliv programu na počet tř́děných odpadů $\left(t=2,24, p=0,03\right.$ - viz pozn. $\left.{ }^{4}\right)$. Nepodařilo se také naměřit vliv programu na vztahy žáků ve tř́dě, byt́ podle výpovědí pedagogů byly pozitivní.

$\mathrm{Na}$ základě provedené evaluace byly středisku navrženy změny týkající se tematického rámce programu, výstupů i metod měření pro příští rok.

\section{Výsledky sumativní evaluace}

V první části evaluace byly porovnávány výsledky mezi experimentální a kontrolní skupinou. Test prokázal statisticky významný rozdíl $v$ porozumění problémům životního prostředí a jejich provázanosti ve prospěch experimentální skupiny.

Tabulka 2: Porovnání skupin na škále Porozumění problémům životního prostředí

\begin{tabular}{|l|l|l|l||l|}
\hline & N & M & W & P \\
\cline { 1 - 3 } Experimentální & 22 & 11,13 & 280 & 0 \\
\cline { 1 - 3 } Kontrolní & 20 & 6,1 & & \\
\hline
\end{tabular}

Pozn.: $N$ udává počet respondentů, $M$ průměrný bodový zisk, $W$ hodnotu Wilcoxonova nepárového testu a p pravděpodobnost náhodného vzniku rozdílů mezi oběma skupinami.

Největší rozdíly byly zaznamenány u otázek zkoumající znalost výroby bavlny a jejích dopadů na životní prostředí.

Zatímco rozdíl $v$ porozumění konkrétním možnostem, které mají žáci pro snížení dopadů textilu na životní prostředí, nebyl statisticky průkazný, žáci z experimentální skupiny prokázali významně vyšší znalosti ekoznaček:

Tabulka 3: Porovnání skupin ve znalostech ekoznaček

\begin{tabular}{|l|l|l|l|l|l|}
\hline & N & MAX & M & W & P \\
\cline { 1 - 5 } Experimentální & 22 & 21 & 7,45 & 253,5 & 0 \\
\cline { 1 - 2 } \cline { 1 - 2 } & 20 & & 3 & & \\
\hline
\end{tabular}

\footnotetext{
${ }^{4}$ Hladina významnosti byla stanovena na $a=0,05$, takže zjednodušeně by šlo tento výsledek označit jako statisticky významný. Vzhledem k malému počtu respondentů byl ale volen opatrnější postup a kromě souhrnných výsledků žáků obou tříd byla statistická významnost hodnocena i pro každou třídu zvláští. $v$ těchto menších skupinách byla hodnota $\mathrm{p}$ vyšší než hladina významnosti. Domníváme se proto, že výsledek nelze jednoduše považovat za statisticky významný a při jeho interpretaci používáme opatrnější formulaci.
} 
Pozn.: N udává počet respondentů, M průměrný bodový zisk, MAX maximální možný počet bodů, W hodnotu Wilcoxonova nepárového testu a p pravděpodobnost náhodného vzniku rozdílů mezi oběma skupinami.

Zatímco v preferencích obou skupin ve vztahu k ekologicky příznivějším jogurtům nejsou statisticky významné rozdíly, ty se projevily $v$ preferencích ekologicky šetrnější čokolády členy experimentální skupiny (jako ekologicky šetrnější byly považovány výrobky se značkou BIO či Fair Trade):

Tabulka 4: Porovnání skupin v jejich odhodlání jednat

\begin{tabular}{|c|c|c|c|c|c|c|c|c|}
\hline & \multicolumn{2}{|c|}{ Jogurty } & \multirow[t]{2}{*}{$x$} & \multirow[t]{2}{*}{$p$} & \multicolumn{2}{|c|}{ Čokolády } & \multirow[t]{2}{*}{$\mathbf{x}$} & \multirow[t]{2}{*}{$\mathrm{p}$} \\
\hline & EKO & NEKO & & & NEKO & EKO & & \\
\hline Experimentální & 11 & 11 & \multirow[t]{2}{*}{2,78} & \multirow[t]{2}{*}{0,096} & 7 & 15 & \multirow[t]{2}{*}{9,82} & \multirow[t]{2}{*}{0,002} \\
\hline Kontrolní & 5 & 15 & & & 16 & 4 & & \\
\hline
\end{tabular}

Pozn.: EKO udává počet respondentů, kteří volili výrobek s ekoznačkou, NEKO počet respondentů, kteři volili výrobek bez ekoznačky. X udává hodnotu chí kvadrátu, p pravděpodobnost náhodného vzniku rozdílư mezi oběma skupinami.

Ve spotřebitelském chování deklarovali žáci z experimentální skupiny významně vyšší počet zakoupených výrobků se značkou Fair Trade a na hranici průkaznosti vyšší počet výrobků se značkou BIO. V počtu zakoupených výrobků se značkou FSC nebyly mezi žáky statisticky významné rozdíly.

Tabulka 5: Rozdíly ve spotřebitelském chování obou skupin

\begin{tabular}{|c|c|c|c|c|c|c|c|c|c|c|}
\hline & & \multicolumn{3}{|l|}{ BIO } & \multicolumn{3}{|c|}{ Fair Trade } & \multicolumn{3}{|l|}{ FSC } \\
\hline & $N$ & M & W & $p$ & $M$ & W & $p$ & $M$ & W & $p$ \\
\hline Experimentální & 21 & 2,66 & \multirow[t]{2}{*}{345} & \multirow[t]{2}{*}{0,052} & 1,28 & \multirow[t]{2}{*}{301} & \multirow[t]{2}{*}{0,001} & 0,05 & \multirow[t]{2}{*}{410,5} & \multirow[t]{2}{*}{0,81} \\
\hline Kontrolní & 20 & 1,75 & & & 0,1 & & & 0,09 & & \\
\hline
\end{tabular}

Pozn.: $N$ udává počet respondentů, $M$ prưměrný bodový zisk, $W$ hodnotu Wilcoxonova nepárového testu a p pravděpodobnost náhodného vzniku rozdílư mezi oběma skupinami.

Nejčastěji uváděnými výrobky byly čokoláda, mléko, jogurty, sušené ovoce, bonbony, sušenky.

Validitu výsledků může zpochybnit skutečnost, že žáci měli v průběhu programu možnost samostatně si kupovat výrobky $v$ bio obchůdku střediska. To mohlo ovlivnit předpokládanou intervenující proměnnou, tj. dostupnost ekologicky př́znivějších výrobkü, která mimo města ještě není př́liš vysoká. Dosažené výsledky proto spíše indikují odhodlání respondentů jednat, je-li k tomu příležitost. 
Ve druhé části evaluace byly výsledky žáků z experimentální skupiny porovnávány $\mathrm{s}$ předem stanovenými indikátory, definujícími kritéria úspěchu (tučně jsou vyznačeny naplněné indikátory):

Tabulka 6: Míra dosažení indikátorů

\begin{tabular}{|l|l|}
\hline $\begin{array}{l}\text { Žák vysvětlí význam ekoznaček a identifikuje podle nich výrobky s nižším } \\
\text { dopadem na životní prostředí. }\end{array}$ \\
\hline Indikátory & $\begin{array}{l}\text { Skutečnost } \\
(\%)\end{array}$ \\
\hline $30 \%$ žáků pozná ekoznačku FSC. & $\mathbf{8 1 , 8}$ \\
\hline $15 \%$ žáků pojem FSC vysvětlí na nejméně 50\% hodnocení. & $\mathbf{3 6 . 3}$ \\
\hline $100 \%$ žáků pozná ekoznačku Fair Trade výrobku. & $\mathbf{1 0 0}$ \\
\hline $75 \%$ žáků vysvětlí význam Fair Trade na nejméně 70\% hodnocení. & 22.7 \\
\hline $100 \%$ žáků pozná podle loga biopotravinu. & 90.9 \\
\hline $75 \%$ žáků vysvětlí pojem biopotraviny na nejméně 70\% hodnocení. & 4.5 \\
\hline Żă
\end{tabular}

Žák vysvětlí, jak se získává bavlna a popíše dopady pěstování bavlny na ŽP a na pěstitele v zemích třetího světa.

$60 \%$ žáků popíše se správností $60 \%$ jaké práce probíhají na obrázcích $\mathrm{v}$ testu.

30 \% žáků popíše se správností 50\% dopady pěstování bavlny na ŽP a pěstitele $v$ zemích 3 . světa.

77,2

45,4

Žák vysvětlí, jak souvisí dopady výroby oblečení s jeho spotřebním chováním, vyjmenuje alternativy.

$30 \%$ žáků vyjmenuje alespoň 1 možnost, jak může pozitivně svým spotřebitelským chováním ovlivnit dopady textilní výroby.

31,8

Žák vysvětlí, co je palmový olej, jak souvisí s jeho spotřebním chováním. Žák popíše souvislost mezi spotřebou palmového oleje a kácením deštných pralesů.

$25 \%$ žáků vyjmenuje využití palmového oleje na 70\% hodnocení

(zisk nejméně dva body)

$25 \%$ uvede, že deštné pralesy se kácí za účelem zvětšení plochy na plantáže (např. palmy olejné) (50\%).

31,8

Z dostupných dat nelze hodnotit

Žák popíše, jaký dopad má kácení pralesů na místní obyvatele, na ŽP Země

40 \% žáků uvede alespoň 1 dopad kácení deštných pralesů (na ŽP nebo místní obyvatele).

15 \% žáků uvede alespoň 2 dopady kácení deštných pralesů (na ŽP nebo místní obyvatele).

81,8

Žák vysvětlí pojem „dětská práce".

$50 \%$ žáků se správností 70\% vysvětlí, co je dětská práce ( 2 a více bodů).

Žák vysvětlí, jak souvisí konzumace čokolády (v ČR) s dětskou prací v rozvojových zemích.

\begin{tabular}{|l}
$25 \%$ žáků vysvětlí souvislost mezi konzumací čokolády a dětskou prací \\
$Z$
\end{tabular} dostupných 


\begin{tabular}{|l|l|}
\hline ... na 70 \% hodnocení & \multicolumn{2}{|l|}{$\begin{array}{l}\text { dat nelze } \\
\text { hodnotit }\end{array}$} \\
\hline $\begin{array}{l}\text { Žák vyjmenuje a vysvětlí alternativy ke konvenční výrobě a obchodování } \\
\text { s čokoládou. }\end{array}$ \\
\hline $\begin{array}{l}75 \% \text { žáků v testu zmíní / vybere FT jako alternativu ke konvenčnímu } \\
\text { pěstování a obchodování s čokoládou. }\end{array}$ & 68 \\
\hline $\begin{array}{l}\text { Žák preferuje ve svém spotřebitelském chování výrobky s nižšími ekologickými } \\
\text { a sociálními dopady. }\end{array}$ & \multicolumn{2}{|l|}{50 (jogurt) /68 } \\
\hline \begin{tabular}{l}
$80 \%$ žáků si v testu vybere čokoládu Fair trade či BioFT. \\
\hline $50 \%$ žáků si v roce 2009 koupilo alespoň 1 FT výrobek.
\end{tabular} & $\mathbf{5 9}$ \\
\hline $50 \%$ žáků si v roce 2009 koupilo alespoň 2 BIO výrobky. & $\mathbf{6 3}$ \\
\hline
\end{tabular}

Po ukončení programu byli žáci požádáni o písemnou reflexi toho, co se v programu naučili. Odpovědi byly kódovány a kategorizovány a byla vyznačena četnost výskytu jednotlivých kódů:

Tabulka 7: Kódování závěrečných reflexí

\begin{tabular}{|c|c|c|c|}
\hline Kategorie & Podkategorie & Četnost & Příklady \\
\hline \multirow[t]{4}{*}{ Původ věcí } & Výroba čokolády & 4 & \multirow{4}{*}{$\begin{array}{l}\text { "Čokoláda se vyrábí z kakaových } \\
\text { bobů a dozvěděl jsem se postup prii } \\
\text { její výrobě." }\end{array}$} \\
\hline & Palmový olej & 2 & \\
\hline & Pěstování bavlny & 3 & \\
\hline & Globální obchod & 3 & \\
\hline \multirow[t]{3}{*}{ Globální problémy } & Chudoba & 1 & \multirow{3}{*}{$\begin{array}{l}\text { "Dozvěděla jsem se všechno } \\
\text { o Číně, Indii, Keně, Ghaně, třeba } \\
\text { že tam děti pracují a někde i } \\
\text { musej, jinak je zabijou. Sbírají tam } \\
\text { boby (kakaové) a postřikují } \\
\text { chemickými prostředky, tak někteři } \\
\text { i umřou. } \\
\text { Z těch bobů vyrábí čokoládu, běžně } \\
\text { je to zdroj jejich obživy." }\end{array}$} \\
\hline & Kácení pralesů & 2 & \\
\hline & Dětská práce & 5 & \\
\hline \multirow[t]{4}{*}{ Akční strategie } & Fair Trade & 11 & \multirow{4}{*}{$\begin{array}{l}\text { "Fair trade je spravedliví obchod. } \\
\text { Ve kterém nepracují děti ale } \\
\text { dospělí. Děti místo toho chodí do } \\
\text { školy. Jejich rodiče dostanou více } \\
\text { peněz." }\end{array}$} \\
\hline & $\mathrm{BIO}$ & 1 & \\
\hline & Třídění odpadu & 1 & \\
\hline & Secondhand & 1 & \\
\hline Kulturní diverzita & $\begin{array}{l}\text { Život v jiných } \\
\text { zemích }\end{array}$ & 8 & $\begin{array}{l}\text { Dozvěděl jsem se o výrobárně } \\
\text { v Číně. Jaké tam mají problémy } \\
\text { v továrnách." }\end{array}$ \\
\hline
\end{tabular}


Nejčastěji uváděnými kategoriemi v závěrečných žákovských reflexích byl Původ věcí a Akční strategie. Nejčastější podkategorií pak Fair Trade, Život v jiných zemích a Dětská práce. To dokresluje zjištění o efektu programu v oblasti porozumění globálním problémům a jejich vztahem ke spotřebitelskému chování žáků a v oblasti znalostí ekoznaček.

Žáci z experimentální skupiny byli po ukončení programu testováni pomocí Scio testu Stonožka 2008/09 pro 7. a 8. tř́ídy: Postojová a dovednostní část klíčových kompetencí. V oblasti ekologického chování žáci dosáhli více než 95 percentilu (průměr pro školy daného typu leží přibližně pod padesátým percentilem). Vzhledem k tomu, že metodika testování není veřejně př́stupná a chybí zdroj pro porovnání, nelze tuto informaci brát jinak, než jako doplňující.

Přestože se některá data nepodařilo při evaluaci naměřit, je zřejmé, že program naplnil většinu stanovených indikátorů. Ze samotného vyhodnocení indikátorů není ještě možné usuzovat na skutečný efekt programu (Poister, 2004). V porovnání s výsledky kontrolní skupiny se ale zdá být alespoň v některých oblastech pravděpodobný.

\section{Diskuse}

Z povahy kvazi-experimentu i z velikosti vzorku nelze $z$ výsledků evaluace tvořit jednoznačné závěry (Reichardt \& Mark, 2004). Na základě všech výsledků se ale zdá pravděpodobné, že program u žáků pozitivně ovlivnil jejich porozumění vybraným globálním problémům, znalosti ekoznaček a odhodlání kupovat si ekologicky šetrnější výrobky. Vliv programu na spotřebitelské chování žáků je možný, byt́ ne zcela průkazný.

$Z$ evaluace není zřejmé, jak by program fungoval, pokud by se omezil pouze na poslední pobytovou akci. Je možné, že se $v$ prvním roce programu podařilo kromě naměřených efektů $v$ kognitivní oblasti rozvinout i základní environmentální povědomí žáků, díky kterému mohl program lépe dosáhnout svých cílů. Pro ověření takové domněnky by ale bylo nutné vyhodnotit po první části vliv programu na environmentální senzitivitu žáků a další související proměnné.

Specifickým rysem programu je také jeho délka. Předpokládá se, že delší programy jsou efektivnější, než krátké, resp. že aby byl program efektivní, musí být (zejména pro mladší účastníky) nejméně jednodenní (Zelezny, 1999). Víceleté programy environmentální výchovy jsou dosud $v$ České republice velmi netypické 5 a bylo by proto zajímavé ověřit, zda a do jaké míry představují přidanou hodnotu proti obvyklejšímu formátu krátkých výukových programů či jednorázových pobytových akcí. Takové ověřování ale bude možné až po větší konsolidaci programu.

$Z$ evaluace jediné třídy také není možné odhadovat, do jaké míry je program citlivý např́klad na vztahy ve skupině či vzdělávací program zapojených škol. Program cíleně pracuje se skupinovou dynamikou (Johnson \& Johnson, 2006) a snaží se formovat vztahy ve skupině. Zůstává nejasné, do jaké míry se mu je daří ovlivňovat a jak by efektivitu programu ovlivnila hůře fungující skupina.

5 Např. v roce 2006 bylo $v$ rámci středisek ekologické výchovy sdružených do SSEV Pavučina zorganizováno 8315 jednodenních programů pro 162108 účastníků a pouze 425 pobytových akcí s celkovou délkou 817 dní pro celkem 5278 účastníků. Krátké programy se tedy realizují téměř dvacetkrát častěji, než pobytové (Daňková, 2007). Dlouhodobější charakter mají dále projekty pro školy, jako je GLOBE či Ekoškola. Tyto programy však jednak nejsou početné, jednak mají odlišný charakter - realizující středisko poskytuje metodiku učitelům, kteří je pak podle ní implementují na svých školách. Jiný český víceletý program, kde by $v$ roli pedagogù byli po celou dobu lektoři střediska ekologické výchovy, není autorům znám. 
Spolu s vývojem programu se zdá být nezbytné vyvíjet i metodiku jeho evaluace. Stávající systém sice umožňuje získat orientační informace o fungování programu, ty jsou ale zatíženy značnou nejistotou. Pro další ročníky Ize doporučit zachování smíšeného evaluačního designu, ale rozšíření jeho kvazi-experimentální části o porovnávání stavu před a po programu. Vzhledem $\mathrm{k}$ délce programu je také vhodné testovat program po každém roce, tedy design přerušované časové série (Interrupted Time-Series Designs) (Reichardt \& Mark, 2004). Test měříí znalost akčních strategií by měl být modifikován tak, aby se zvýšila jeho položková reliabilita.

Pokud by se opakovaně podařilo potvrdit funkčnost použité metodiky, znamenalo by to cenný příspěvek do diskuse o efektivitě jednotlivých strategií environmentální výchovy. $\mathrm{Na}$ rozdíl od anglosaské oblasti, ve které se pro analýzu a řešení problémů uplatňují především různé formy projektové výuky (Bardwell, Monroe \& Tudor, 1994; Marcinkowski, 2004), jsou aktivity programu založeny především na sledu lektory řízených her a diskusí. Důraz na hry a naopak menší využití projektové metodiky může být charakteristickým rysem české tradice environmentální výchovy. Je proto důležité sledovat, do jaké míry je tato alternativa funkční.

\section{Závěry}

Článek prezentoval výsledky sumativní evaluace druhého ročníku nového pobytového programu Podblanického ekocentra ČSOP Vlašim. Protože se program stále ještě nachází v experimentální fázi, nelze její výsledky zobecňovat. Vzhledem k velikosti skupiny i povaze kvazi-experimentu je evaluace poznamenána dílčími nepřesnostmi a její výpovědní hodnota je proto nižší, než pokud by bylo možné provést randomizovaný experiment. Výsledky je proto možné považovat pouze za orientační, jejich význam spočívá především ve zpětné vazbě tvưrcưm programu. Současně článek ilustruje problémy, související s evaluací nového programu. Přestože sumativní evaluace programů environmentální výchovy nejsou v České republice dosud rozšířené, Ize předpokládat, že při jejich zavádění často narazí tvưrci programu na situace, kdy nebude možné použít ideální evaluační design a bude třeba snažit se získat zpětnou vazbu s použitím méně spolehlivých metod.

Prezentovaná evaluace dále otevírá specifické otázky související s metodikou environmentální výchovy, jako je vliv délky programu, skupinové dynamiky či jiných proměnných na efektivitu programu. Těmto otázkám se bude třeba věnovat $v$ dalších navazujících pracích.

V neposlední řadě článek naznačuje potenciál nového programu a jeho metodiky, který ještě bude nutné dále vyhodnocovat.

\section{Použitá literatura}

- Bardwell, L. V., Monroe, M. C., \& Tudor, M. T. (1994). Environmental Problem Solving. Theory, Practice and Possibilities in Environmental Education. Troy: NAAEE.

- Barch, B., Duvall, J., Higgs, A., Wolske, K., \& Zint, M. . Planning and Implementing an EE Evaluation. . Retrieved from http://66.135.39.45:7080/meera-dev/knowledge-base/plan-anee-evaluation/

- Bennett, D. B. (1989). Evaluating Environmental Education in Schools. A practical guide for teachers. : UNESCO - UNEP, Division of Science, Technical and Environmental Education. Retrieved from http://unesdoc.unesco.org/images/0006/000661/066120eo.pdf

- Činčera, J. (2009). Evaluace programů environmentální výchovy. Brno: MU. 
- Činčera, J. (2007). Práce s hrou. Pro profesionály. Praha: Grada.

- Činčera, J., Kulich, J., \& Gollová, D. (2009). Efektivita, evaluace a podpora programů environmentální výchovy. Envigogika, 4(2), Retrieved from http://www.envigogika.cuni.cz/index.php/Envigogika/article/view/3

- Daňková, L. (2007). Výroční zpráva 2006. Sdružení středisek ekologické výchovy Pavučina. Praha: SSEV Pavučina.

- FRECHTLING, Joy et. al, (2002). The 2002 User-Friendly Handbook for Project Evaluation. : The National Science Foundation. Retrieved http://www.nsf.gov/pubs/2002/nsf02057/nsf02057.pdf

- Hendl, J. (2008). Kvalitativní výzkum. Základní teorie, metody a aplikace. Praha: Portál.

- Hendl, J. (2006). Přehled statistických metod. Praha: Portál.

- Hungerford, H. R., \& Volk, T. L. (1990). Changing Learner Behavior Through Environmental Education. The Journal of Environmental Education. The Journal of Environmental Education, 21(3), 8-21. Retrieved from http://www.tandfonline.com/doi/abs/10.1080/00958964.1990.10753743 http://dx.doi.org/10.1080/00958964.1990.10753743

- Johnson, D. W., \& Johnson, F. P. (2006). Joining Together. Group Theory and Group Skills. Boston: Pearson.

- Kovalik, S. J., \& Olsen, K. D. (1994). Kid's eye view of science. A Teacher's Handbook for Implementing an Integrated Thematic Approach to Teaching Science, K-6. Kent: Center for the Future of Public Education.

- McLAughlin, J. A., \& Jordan, G. B. (2004). Using Logic Models. San Francisco: Jossey-Bass.

- Marcinkowski, T. (2004). Using a Logic Model to Review and Analyze an Environmental Education Program. Washington: North American Association for Environmental Education.

- Newcomer, K. E., Wholey, J. S., \& Hatry, H. P. (2004) Meeting the Need for Practical Evaluation Approaches: An Introduction. In Handbook of Practical Program Evaluation. San Francisco: Jossey-Bass.

- Newcomer, K. E., \& Wirtz, P. W. (2004). Using Statistics in Evaluation. In Handbook of Practical Program Evaluation. San Francisco: Jossey-Bass.

- Poister, T. H. (2004) Performance Monitoring. In Wholey , J S Hatry H P, \& K. E. Newcomer (Eds.), Handbook of Practical Program Evaluation (pp. 98-125). San Francisco: Jossey-Bass.

- Reichardt, C. S., \& Mark, M. M. (2004) Quasi-Experimentation. In J. S. Wholey, H. P. Hatry, \& K. E. Newcomer (Eds.), Handbook of Practical Program Evaluation(pp. 126-149). San Francisco: Jossey-Bass.

- Zelezny, L. C. (1999). Educational Interventions That Improve Environmental Behaviors: A Meta-Analysis. The Journal of Environmental Education, 31(1), 5-14. Retrieved from http://www.tandfonline.com/doi/abs/10.1080/00958969909598627 http://dx.doi.org/10.1080/00958969909598627

- Vlašim, Z. . (2007). Expedice 4P [prezentace, interní materiál]. Vlašim: Podblanické ekocentrum ČSOP Vlašim.

\section{Př́lohy}

Př́loha č. 1 Indikátory pro formativní evaluaci programu 


\begin{tabular}{|c|c|c|c|}
\hline с̌. & Specifické výstupy/indikátory & Vliv programu & Doporučení \\
\hline 1 & $\begin{array}{l}\text { 70\% žáků program hodnotí jako } \\
\text { velmi dobrý nebo výborný }\end{array}$ & $\begin{array}{l}\text { Splněno, míru } \\
\text { spokojenosti nelze } \\
\text { zcela kvantifikovat. }\end{array}$ & $\begin{array}{l}\text { Doplnit evaluaci } \\
\text { o kvantitativní } \\
\text { hodnocení } \\
\text { spokojenosti. }\end{array}$ \\
\hline 2 & $\begin{array}{l}\text { Učitelé všech zapojených tříd } \\
\text { hodnotí program jako velmi dobrý } \\
\text { nebo výborný }\end{array}$ & Splněno. & \\
\hline 3 & $\begin{array}{l}\text { 70\% žáků správně uvede alespoň } \\
\text { jednu zajímavou přírodní či } \\
\text { kulturní lokalitu v regionu }\end{array}$ & $\begin{array}{l}\text { Splněno, ale bez vlivu } \\
\text { programu. }\end{array}$ & $\begin{array}{l}\text { Rozšírit zastoupení } \\
\text { tématu nebo jej zrušit. }\end{array}$ \\
\hline 4 & $\begin{array}{l}\text { 50\% žáků je spokojeno s místem, } \\
\text { ve kterém žije }\end{array}$ & $\begin{array}{l}\text { Splněno, ale bez vlivu } \\
\text { programu. }\end{array}$ & $\begin{array}{l}\text { Rozšírit zastoupení } \\
\text { tématu nebo jej zrušit. }\end{array}$ \\
\hline 5 & $\begin{array}{l}\text { 70\% žáků hodnotí pobyt v prírodě } \\
\text { jako atraktivní }\end{array}$ & $\begin{array}{l}\text { Nesplněno, možný } \\
\text { malý vliv programu na } \\
\text { posun postoje. }\end{array}$ & $\begin{array}{l}\text { Doplnit dotazník o další } \\
\text { položky vyhodnocující } \\
\text { environmentální } \\
\text { senzitivitu. }\end{array}$ \\
\hline 6 & $\begin{array}{l}\text { 70\% žáků vysvětlí na alespoň } \\
\text { 70\% bodů význam značek Fair } \\
\text { Trade, Bio a Klasa }\end{array}$ & $\begin{array}{l}\text { Nesplněno, ale velmi } \\
\text { vysoký vliv programu } \\
\text { na získání znalostí. }\end{array}$ & $\begin{array}{l}\text { Snížit kritérium } \\
\text { úspěšnosti. }\end{array}$ \\
\hline 7 & $\begin{array}{l}\text { 70\% žáků vyjmenuje se } \\
\text { správností nejméně } 70 \% \\
\text { složení zadaného potravinářského } \\
\text { výrobku }\end{array}$ & $\begin{array}{l}\text { Částečně splněno, } \\
\text { velmi vysoký vliv } \\
\text { programu na získání } \\
\text { znalostí. }\end{array}$ & $\begin{array}{l}\text { Upravit korespondenci } \\
\text { s obecným výstupem } \\
\text { programu. }\end{array}$ \\
\hline 8 & $\begin{array}{l}\text { 70\% žáků správně } \\
\text { vysvětlí environmentální } \\
\text { a společenské dopady životního } \\
\text { cyklu zadaného výrobku }\end{array}$ & $\begin{array}{l}\text { Nelze zcela vyhodnotit. } \\
\text { Vliv programu velmi } \\
\text { pravděpodobný. }\end{array}$ & $\begin{array}{l}\text { Promyslet nový systém } \\
\text { evaluace tohoto } \\
\text { výstupu. }\end{array}$ \\
\hline 9 & $\begin{array}{l}\text { 70\% žáků realizuje ve skupině } \\
\text { projekt, který ve všech svých } \\
\text { fázích splní zadaná kritéria }\end{array}$ & $\begin{array}{l}\text { Nelze zcela vyhodnotit. } \\
\text { Vliv programu na } \\
\text { související dovednosti } \\
\text { možný. }\end{array}$ & $\begin{array}{l}\text { Promyslet nový systém } \\
\text { evaluace, nejlépe } \\
\text { založený na kriteriální } \\
\text { tabulce pro jednotlivé } \\
\text { projekty. }\end{array}$ \\
\hline 10 & $\begin{array}{l}50 \% \text { žáků volí ve volném čase } \\
\text { možnost být v přírodě }\end{array}$ & $\begin{array}{l}\text { Nesplněno. } \\
\text { Vliv programu } \\
\text { nepravděpodobný. }\end{array}$ & $\begin{array}{l}\text { Zvážit, zda zachovat } \\
\text { výstup a prípadně } \\
\text { zpřesnit jeho měření. }\end{array}$ \\
\hline 11 & $\begin{array}{l}70 \% \text { žáků třídí doma alespoň čtyři } \\
\text { různé druhy odpadu }\end{array}$ & $\begin{array}{l}\text { Nesplněno. } \\
\text { Vliv programu možný, } \\
\text { ale málo } \\
\text { pravděpodobný. }\end{array}$ & $\begin{array}{l}\text { Zvážit, zda zachovat } \\
\text { výstup a prípadně } \\
\text { posílit související } \\
\text { aktivity v programu. }\end{array}$ \\
\hline 12 & $\begin{array}{l}\text { 50\% žáků se při výběru výrobku } \\
\text { řídí podle země pưvodu a šetrnosti } \\
\text { k životnímu prostředí }\end{array}$ & Nelze vyhodnotit. & $\begin{array}{l}\text { Promyslet nový systém } \\
\text { evaluace tohoto } \\
\text { výstupu. }\end{array}$ \\
\hline 13 & $\begin{array}{l}50 \% \text { žáků a všichni učitelé hodnotí } \\
\text { vzájemnou spolupráci a vztahy ve } \\
\text { tř́dě jako lepší oproti stavu před } \\
\text { zahájením programu. }\end{array}$ & $\begin{array}{l}\text { Částečně splněno } \\
\text { (hodnocení učitelů). } \\
\text { Vliv programu } \\
\text { pravděpodobný, ale } \\
\text { spíše menší. }\end{array}$ & $\begin{array}{l}\text { Promyslet nový systém } \\
\text { evaluace tohoto } \\
\text { výstupu. }\end{array}$ \\
\hline
\end{tabular}


Více najdete na internetových stránkách projektu mosur.czp.cuni.cz
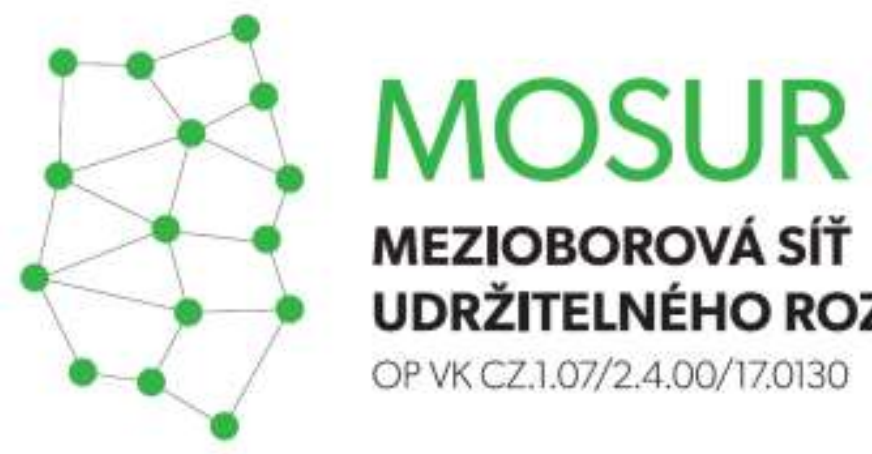

\section{MEZIOBOROVÁ SÍT} UDRŽITELNÉHO ROZVOJE

OP VK CZ.1.07/2.4.00/17.0130
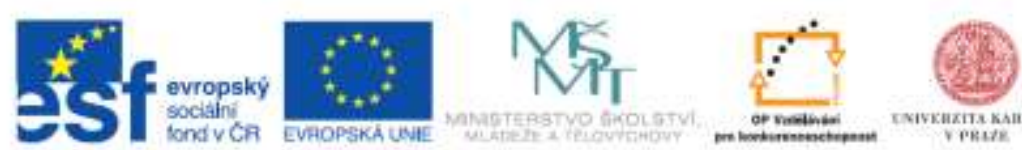

INVESTICE DO ROZVOJE VZDELAVANI 